Man and Nature

MAN AND NATURE

L'homme et la nature

L'HOMME ET LA NATURE

\title{
Robinson Crusoe, Friday, and the Noble Savage: The Illustration of the Rescue of Friday Scene in the Eighteenth Century
}

\section{David Blewett}

Volume 5, 1986

URI : https://id.erudit.org/iderudit/1011850ar

DOI : https://doi.org/10.7202/1011850ar

Aller au sommaire du numéro

Éditeur(s)

Canadian Society for Eighteenth-Century Studies / Société canadienne d'étude du dix-huitième siècle

ISSN

0824-3298 (imprimé)

1927-8810 (numérique)

Découvrir la revue

Citer cet article

Blewett, D. (1986). Robinson Crusoe, Friday, and the Noble Savage: The Illustration of the Rescue of Friday Scene in the Eighteenth Century. Man and

Nature / L'homme et la nature, 5, 29-49. https://doi.org/10.7202/1011850ar

Copyright (c) Canadian Society for Eighteenth-Century Studies / Sociéte canadienne d'étude du dix-huitième siècle, 1986
Ce document est protégé par la loi sur le droit d'auteur. L'utilisation des services d'Érudit (y compris la reproduction) est assujettie à sa politique d'utilisation que vous pouvez consulter en ligne.

https://apropos.erudit.org/fr/usagers/politique-dutilisation/ 


\section{Robinson Crusoe, Friday, and the Noble Savage: The Illustration of the Rescue of Friday Scene in the Eighteenth Century}

Visual representation of Crusoe's Man Friday underwent a remarkable development during the course of the eighteenth century. In part this change is due to the sheer number and greater sophistication of the later illustrations, which permitted much more scope for the expression of the relationship between the two men, but the development of interest in Friday also reflects changing European attitudes toward primitive people and people of other races generally. ${ }^{1}$

Robinson Crusoe was published in 1719 by a group of booksellers led by William Taylor, its only illustration the famous frontispiece portrait of Crusoe standing desolate on the shore of his island, engraved by Clark and Pine [Pl. I]. ${ }^{2}$ But so great was the popularity of the book that in the sixth edition in 1722 a series of six, rather weak, illustrations was added. ${ }^{3}$ Typical of the additional illustrations is the one showing the rescue of Friday, a mere diagrammatic outline of the stages, happening simultaneously, in the drama of the rescue [Pl. II]. On one side of the creek, where the cannibals are being untied, we see Friday begging for his life. On the other side of the creek, we see Crusoe's stockade in the background and Crusoe, in the middleground, shooting the menacing Indian, while Friday makes his escape. Between Crusoe and his stockade 
Friday is again depicted, humbling himself before Crusoe. As with certain Sienese primitives, we are meant to 'read' the design chronologically and, in this case, in a roughly circular, anti-clockwise, direction.

Two years before the publication of this illustration, the first French translation of Crusoe had been published with a fine frontispiece portrait of Crusoe by the distinguished French artist, Bernard Picart, and a series of six unsigned illustrations, including a rescue scene [Pl. III]. ${ }^{4}$ Though the engraving is undistinguished, the superiority of eighteenth-century French book illustration is immediately evident. In the background we see the dancing cannibals preparing for their feast, oblivious of the momentous events that are revealed to us in the foreground. Following Defoe's text, the artist depicts the moment at which Friday, having decapitated his enemy, returned Crusoe's sword and laid it down with the Head of the Savage, that he had kill'd just before me. ${ }^{5}$ The composition, by placing Crusoe and Friday in the foreground, gives appropriate emphasis to the principals in the drama. Friday raises Crusoe's foot preparatory to placing it on his head to indicate his subservience, while Crusoe extends his hand in a benign gesture, almost of blessing. The two dead savages lying near-by remind us of the violent events which have just occurred, while they lead the eye into the picture where the other savages are engaged in their gruesome antics; but they do not detract from the vital scene which establishes the important relationship between master and servant that is in the forefront of our attention. The stream that divides the foreground from the background, as in the naive English illustration but more effectively, also divides Crusoe's terrain from that of the cannibals. We have no doubt that Friday has moved from one world to the other. What the engraving fails to convey is any sense of the personalities of either Friday or Crusoe. The artist is not interested in Crusoe's facial expression, for example, and Friday is essentially indistinguishable from the other savages.

Apart from the chapbooks with their simple, repetitive woodcuts, no new illustrated edition appeared for forty years until, in 1761, a French edition $^{6}$ with a new but anonymous series of designs offered a pictorial echo of the earlier French edition. In the rescue of Friday scene [Pl. IV], as in the other illustrations, a rococo elegance, most noticeable in the curving lines of the trees and the elongated bodies, replaces the baroque energy and weight of the 1720 engravings. A slight but important shift of emphasis, however, now focuses our attention more completely upon Crusoe and Friday, whose gestures indicate their hesitancy and uncertainty as they eye each other warily. The two dead savages and the other cannibals can be detected in the background, but interest is now more fully than ever on the tentative human relationship about to develop. 
The appearance of a French edition with new illustrations points to the fact that throughout much of the eighteenth century Robinson Crusoe was more highly regarded in France than in England. In the following year, 1762, Rousseau published his Emile, in which he promoted Robinson Crusoe as the best treatise on natural education, and a splendid example of the value of acquiring self-sufficiency and hence independence of judgment for the young Emile, who is actively encouraged to identify himself with Crusoe. Rousseau's testimony helped Robinson Crusoe to become a world classic, but it also indicates a significant shift in emphasis from moral admonition to personal involvement, and ultimately to romantic escapism, which may be felt in subsequent illustration.

Twenty five years later in 1787 Charles Garnier published a collection of imaginary voyages, ${ }^{7}$ including Robinson Crusoe, illustrated by Clément Pierre Marillier (1750-1800), one of the foremost book illustrators in France. There are only two engravings in the first part of Robinson Crusoe and one of them is the rescue scene [Pl. V]. The influence of earlier illustrations of this scene can probably be felt in Marillier's general design, but the mood, as well as the much greater technical proficiency, marks the plate off from earlier representations. Crusoe, a man of boundless self-possession, is shown standing with his rifles against a sturdy pine tree - the verticals of rifles and tree emphasizing his masterful stance - as he accepts the submission of the ungainly Friday. The eyecontact of the two men, Crusoe confident and powerful, Friday genuinely uncertain and begging for his life, seems to underline the role of the dominant and submissive personalities in the future relationship between the two. The wildmen in the background appear distinctly unthreatening, more like boys on a picnic than cannibals preparing for a feast.

The first new illustrated edition of Robinson Crusoe to appear in England for sixty years came out in 1781 in the reprint series, The Novelist's Magazine, published by the enterprising Harrison, ${ }^{8}$ with engravings by the young Thomas Stothard (1755-1834). Here Stothard focuses not upon the rescue of Friday but on a later and more pathetic scene in which the faithful and earnest Friday, offering a hatchet to his master, begs Crusoe to kill him rather than send him home to his people [Pl. VI]. The comfortable domesticity that is so much a part of Stothard's vision of Crusoe's life on the island is evident in the reposeful domestic animals in the background. Stothard's depiction of tender moments such as this enlarges the degree of intimacy and affection in the story, shifting its import away from moral instruction and increasing the reader's emotional involment.

Harrison's edition sparked a renewal of interest in Robinson Crusoe and the decade that followed saw the appearance of a glowing account of 
the life of Defoe by George Chalmers (1785) ${ }^{9}$ hailing Robinson Crusoe 'as a poem,' as well as three handsome, illustrated editions of the novel. The romanticizing, even sentimentalizing, of the untamed primitive that is one aspect of the eighteenth-century idealization of the Noble Savage is manifested in the first of these editions, published in 1785 by J. Walter in three volumes. The rescue of Friday provides the frontispiece to Volume I [Pl. VII], the first instance of the elevation of this scene to frontispiece status. The designer was Mather Brown (d. 1831), ${ }^{10}$ an American, born probably in Boston in the middle of the eighteenth century, who studied in England under his countryman, Benjamin West. Dominating the foreground is the triangle composed of Crusoe and the two Indians, a formal device borrowed from Renaissance religious painting. In the background, on either side, can be seen Crusoe's stockade and the dancing cannibals, the alternatives in Friday's life at this critical juncture. Crusoe, ironically, appears far the wilder of the two, a sort of armed John-the-Baptist, offering succour to the young and graceful Friday, a noble savage with distinctly European features. Actually Crusoe is not John-the-Baptist, but a more powerful figure. Stepping miraculously out of nowhere and possessing the inexplicable power of slaying an enemy invisibly, Crusoe appears as a figure of authority, a god or an allpowerful father, as Mather Brown subtly indicates. In a convention descending from Michelangelo, God the Father was represented with hair streaming in the wind, as in Blake's drawing of Urizen, the frontispiece to Europe (1794). Brown's allusion to the convention, the triangular composition, and the spectator's viewpoint (which is on a level with Friday's) serve as formal confirmation of Crusoe's elevation to god-like authority.

In the late eighteenth century attitudes towards people of other races, particularly over the question of slavery, were changing, not only because of interest in the noble savage, but because of the writings and agitation of men such as Thomas Day, Granville Sharp, and Henry Mackenzie, who were in the forefront of a movement that was to culminate in the work of William Wilberforce and the emancipation of the slaves in the British Empire. ${ }^{11}$ Something of that new attitude can be felt in this engraving, and even more distinctly in a design by Charles Ansell, engraved by J. Barlow, and published by William Lane in 1790 [Pl. VIII]. Crusoe, radiating benevolence and enlightenment, has laid aside his rifles while he offers grapes and bread to Friday, who approaches eagerly, now standing rather than humbly kneeling. A jug of water can be seen at Crusoe's feet and behind him the entrance to the cave, while around his head light breaks through the trees, creating a halo-like glow. Any suggestion of violence - dead bodies, cannibal feasting, and so forth - has been cut out. The lemma makes clear the 
essentially sentimental attitude behind this prettified vision of Crusoe's rescuing and protecting Friday in the gentle woodland setting.

The idealization of Friday, which these engravings convey, led to the re-writing of Robinson Crusoe in order to turn Friday from an ordinary cannibal into a prince, literally a noble savage. In one edition that I have seen, printed in Dublin about 1820, Crusoe's description of Friday is altered to include the sentence, 'I had saved the life of an Indian prince, no less graceful and accomplished than the great Oroonoko.'12 For well over a century, since the time Mrs. Behn first used the name for her hero, Oroonoko had been the type of the admirable, but oppressed, primitive nobleman. His association with Friday underscores the transformation that Crusoe's companion underwent in the Romantic period.

The third edition of this decade of revival was the most sumptuous of the three. Published by John Stockdale in 1790 and accompanied, significantly, by Chalmers' Life and extravagant praise of Defoe, it was illustrated by a new set of fourteen drawings by Stothard. ${ }^{13}$ The transformation we have witnessed in Friday as he emerges from impersonality into the idealized primitive man is carried a stage further. No longer a figure of pathos or comedy, and certainly not of grotesque subservience, Friday now assumes the attributes of the Noble Savage, the idealized primitive so much discussed in the eighteenth century, who can take his place as the fit companion to Crusoe [Pl. IX]. Ever since the discovery of the new world in the fifteenth century, Europeans had been projecting onto primitive peoples, above all the North American Indian, qualities they sought within themselves, but which they feared they had lost or had never had. Although he took on different forms for different writers, the noble savage became a convenient symbol for uncorrupted virtue and innate nobility that threw into relief the corruption of European behaviour and institutions. ${ }^{14}$ Crusoe's description of Friday as 'a comely handsome Fellow, perfectly well made; with straight strong Limbs' (205), and his long debate with himself over the question of the barbarity of the cannibals - he concludes that they are no worse than the Spanish reflects Defoe's awareness of contemporary discussion of the topic.

Stothard's pictorial comment on the nobility of Friday is made in the muscular torso, based on antique statues, and the 'noble' face, identified by the long hair, straight nose, and small mouth, found in antique drawings such as those published in Sir William Hamilton's two collections of engravings from ancient vases, and extensively discussed in eighteenthcentury handbooks of caricature and physiognomy. ${ }^{15}$ In this example $[\mathrm{Pl} \text {. X] }]^{16}$ from Hamilton's second collection the noble, his body halfturned, and his face in profile, like Friday's, holds a mask of a peasant head, its features, especially the upturned nose and large lips, a 
caricature of the real peasant. Stothard learned to draw not from life studies, but from copying antique sculpture and the works of Raphael, and he urged all young artists to do the same, but he also, in this instance, has the textual authority of Defoe whose description of Friday emphasizes the noble features of the American Indian: 'His Hair was long and black, not curl'd like wool; his Forehead very high, and large ... his Nose small, not flat like the Negroes, a very good Mouth, thin Lips, and his Teeth well set' (205-6).

Friday stands protected by Crusoe (standing astride the unconscious Indian whom he has just knocked down) and facing the same direction. Except for Crusoe's beard the two faces are alike, though not of course identical, and Crusoe's protective stance, hinting at the father and son relationship that was to develop later, suggests that in some sense Friday is the wild equivalent of Crusoe, a personification, as it were, of the 'Wild Man within' all civilized Europeans. The Friday we see here appears to possess those innately good traits which are the marks of Rousseau's vision of what man would be if not corrupted by society. $\mathrm{He}$ is the primitive self of Crusoe. Crusoe is a civilized European who has been forced to return to a state of nature where he encounters an uncivilized, but noble, savage whom he introduces to the blessings of civilization, Christianity, and clothing. This icon presents the two men, Crusoe and Friday, moving in opposite directions at the point at which they meet.

Stothard's design also differs from earlier illustrations by his elimination of the feasting cannibals usually seen in the distance on the other side of the stream, and by any hint of Friday's slavish gratitude. The world into which Friday has stepped is the idyllic landscape of Stothard's romantic imagination, an idealized world in which a god-like stranger asserts his powerful authority and protection. The manifest threat from Friday's enemies is reduced to the two Indians, one lying stunned on the ground at Crusoe's feet, the other standing puny and ineffective, awkwardly holding his bow and arrow.

Stothard's designs for Stockdale, the reigning illustrations for the next thirty or forty years, mark the high tide of the idealization of Friday as the Noble Savage. Throughout much of the nineteenth century the emphasis in the representation of this scene switches to the killing of Friday's enemy, the menacing savage with his bow and arrow, often in a highly theatrical picture of which Stanley Berkeley's illustration for an edition published in 1890 is typical [PI. XI].17 Moreover, the idealized features of the Noble Savage give way to a more realistic portrayal of African or Indian features, made increasingly familiar to Englishmen as the Empire, communication, and the illustrated magazines expanded. 
Perhaps the last important idealized drawing of the meeting of the well-intentioned Englishman with the gentle and virtuous savage in the tradition I have been outlining is, oddly enough, Cruikshank's frontispiece for an edition of 1831, published by John Major [Pl. VII]. ${ }^{18} \mathrm{Ut}-$ terly uncharacteristic of Cruikshank's usual style of book illustration, which owed much to the popular graphic satire of his day, this frontispiece, the only full-page drawing in the edition, is an indication of the hold the scene had acquired in the minds of readers, or at any rate in the minds of book publishers. Clearly either Major or Cruikshank (and quite possibly both) felt that this important scene should be the one that the reader would encounter as he opened the book at the titlepage. With the exception of Crusoe's stockade, it retains all the features of the BrownPollard frontispiece to the 1785 edition, to which it is clearly indebted [Pl. VII]. A graceful young man with long hair, light-brown skin, and gentle features crouches before a serene and confident Crusoe. Though heavily armed with hatchet, saw, sword, and rifle, Crusoe extends his hand, palm upward, in a non-threatening and traditional gesture of succour. In the background the two dead savages, the stream, and the cannibals dancing around a fire can be seen. Though the tropical vegetation introduces a more or less realistic note rarely struck in the eighteenthcentury illustration, the scene is essentially symbolic, a survival of a central icon in the eighteenth-century imagination, and a powerful image of the meeting of two worlds.

\section{DAVID BLEWETT \\ McMaster University}

\section{NOTES}

1 Interest in primitivism was well established by the eighteenth century and Robinson Crusoe itself, as Kingsley Martin has pointed out, reflects contemporaneous interest in primitive man: 'Jesuit accounts of Hurons and Iroquois reinforce the current picture of the amiable Man Friday in Robinson Crusoe' (French Liberal Thought in the Eighteenth Century, 1929 and 1962, reprinted New York: Harper Torchbook, 1963, Edward Dudley and Maximillian E. Novak, eds., 120). In the later eighteenth century interest in the Noble Savage quickened under the impact of the writings of Rousseau and of the movement to abolish the slave trade. See in particular Maximillian E. Novak, 'The Wild Man Comes to Tea' and Geoffrey Symcox, 'The Wild Man's Return: The Enclosed Vision of Rousseau's Discourses' 
in The Wild man Within: An Image in Western Thought from the Renaissance to Romanticism, Edward Dudley and Maxmillian E. Novak, eds., (Pittsburgh: University of Pittsburgh Press, 1972). Older accounts by Hoxie Neale Fairchild, The Noble Savage: A Study in Romantic Naturalism (New York: Columbia University Press, 1928) and by Paul Hazard, European Thought in the Eighteenth Century (London: Hollis and Carter, 1954), esp. pp. 364-7, are still useful. H.C. Porter's The Inconstant Savage: England and the North American Indian: 1500-1660 (London: Duckworth, 1979) deals with the historical reality rather than with the myth of the North American Indian, but has an interesting postscript on Friday. O. Mannoni offers a fascinating psychological interpretation of Crusoe and Friday in Prospero and Caliban: The Psychology of Colonization, (1950); translated by Pamela Powesland (New York: Frederick A. Praeger, 1964).

2 Clark is probably the shadowy figure of John Clark (fl. 1710-20), who worked with Pine on other occasions, notably an engraving of the Rev'd Samuel Croxall in Giles Jacob's Poetical Register (1719) and a folding map of Crusoe's island, the frontispiece of the Serious Reflection . . . of Robinson Crusoe (1720). John Pine (1690-1756), probably a pupil of Bernard Picart (see below), was one of the most distinguished English engravers of the earlier eighteenth century. His chief works are a series of engravings from the House of Lords tapestry of the destruction of the Spanish Armada and an edition of Horace (1733-37), finely engraved throughout.

3 Percy Muir in his Victorian Illustrated Books (London: Batsford, 1971), citing the examples of Robinson Crusoe and Gulliver's Travels, points out that before the nineteenth century 'illustrations were used only after a novel had proved a suc-

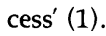

4 Bernard Picart (1673-1733), a major French engraver, who lived and worked in Amsterdam, where the first French edition of Robinson Crusoe was published by L'Honore \& Chatelain in 1720 . This edition was the first to illustrate the novel with more than a frontispiece and maps. Pierre Mornand ('Les Robinson Crusoe: Iconographie de Robinson Crusoe,' Le Portique 7 (1950) 49-64) claims that the illustrations added in the third French edition 1720-21 were copper engraving by Bernard Picart (52). The attribution is unlikely.

5 The Life and Strange Surprizing Adventures of Robinson Crusoe, ed. J. Donald Crowley (London: Oxford University Press, 1972), 204. Subsequent references to this edition are given in parentheses in the text.

6 La Vie at les Avantures surprenantes de Robinson Crusoé (Paris: Chez Cailleau, Dufour, et Cuissart, 1761)

7 Voyages Imaginaires, Songes, Visions, et Romans Cabalistiques (Amsterdam, 1787). The three parts of Robinson Crusoe are to be found in Volumes I - III. The engraver of the rescue of Friday scene was Remi Henri Joseph Delvaux (1748-1823).

8 The fourth volume of The Novelist's Magazine contains Gil Blas and Robinson Crusoe, both illustrated by Stothard. The engraver of the scene showing Friday's profession of loyalty was Joseph Collyer (1748-1827). Austin Dobson in an article on 'Illustrated Books' in Andrew Lang's The Library (London: Macmillan, 1881) cites Stothard's plates for Harrison's Novelist's Magazine (along with Bewick's cuts for Gay's Fables, 1779), as the moment 'that book-illustration by imaginative composition really begins to flourish in England' (124). 
9 The Life of Daniel De Foe (London: J. Stockdale, 1785). Chalmers's Life was subsequently appended to editions of Defoe's History of the Union (1786) and of Robinson Crusoe (London: J. Stockdale, 1790).

10 The engraver was Robert Pollard (c. 1755-1818).

11 Thomas Day (1748-89), author of The Dying Negro (1773) and The History of Sandford and Merton (3 vols. 1783-89); Granville Sharp (1735-1813); Henry Mackenzie (1745-1831), author of The Man of Feeling (1771); William Wilberforce (1759-1833).

12 The Life and most surprising Adventures of Robinson Crusoe of York, Mariner, second edition (Dublin: John Jones, c. 1820), 123. British Library pressmark: $12614 \mathrm{ccc} 21$

13 The engraver was Thomas Medland (d. 1833).

14 See Symcox, esp. pp. 225-9.

15 E.g., Francis Grose. Rules for drawing Caricatures, with an Essay on comic painting, second edition (London, 1719); John Caspar Lavater, Essays on Physiognomy; translated from the French by Henry Hunter; 3 vols (London, 1789-98). Stothard was a subscriber to the English translation of Lavater.

16 Collection of Engravings from ancient vases . . . discovered . . . during . . the years 1789 and 1790. (Naples: W. Tischbein 1791-95) Vol I, Pl. 40

17 (London: Griffith, Farran, Okeden and Welsh 1890), I, 171

18 The engraver was Augustus Fox (fl. 1828-43).

The following plates are reproduced by permission of the British Library. 


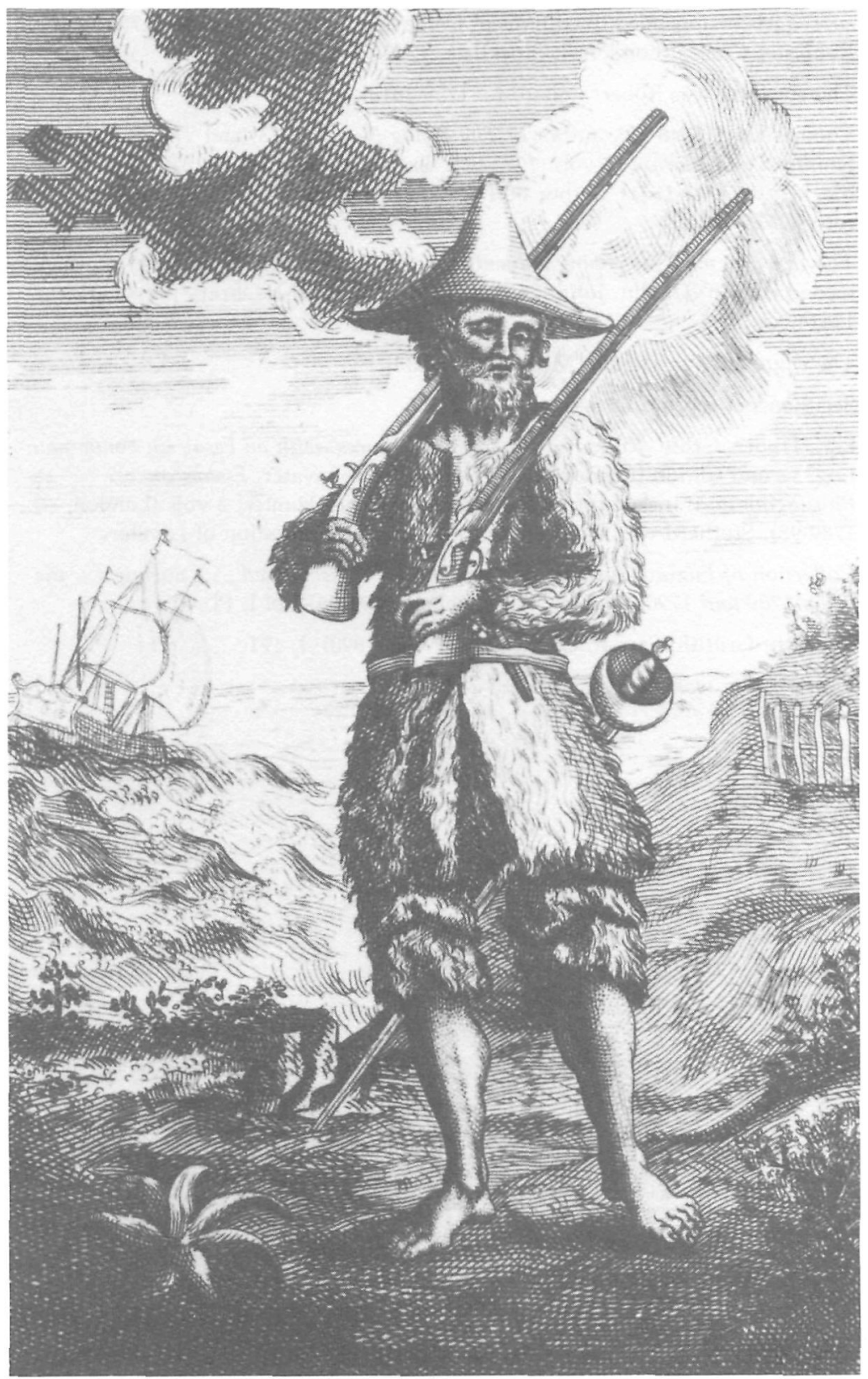

I FP portrait J. Clark - J. Pine 1719 


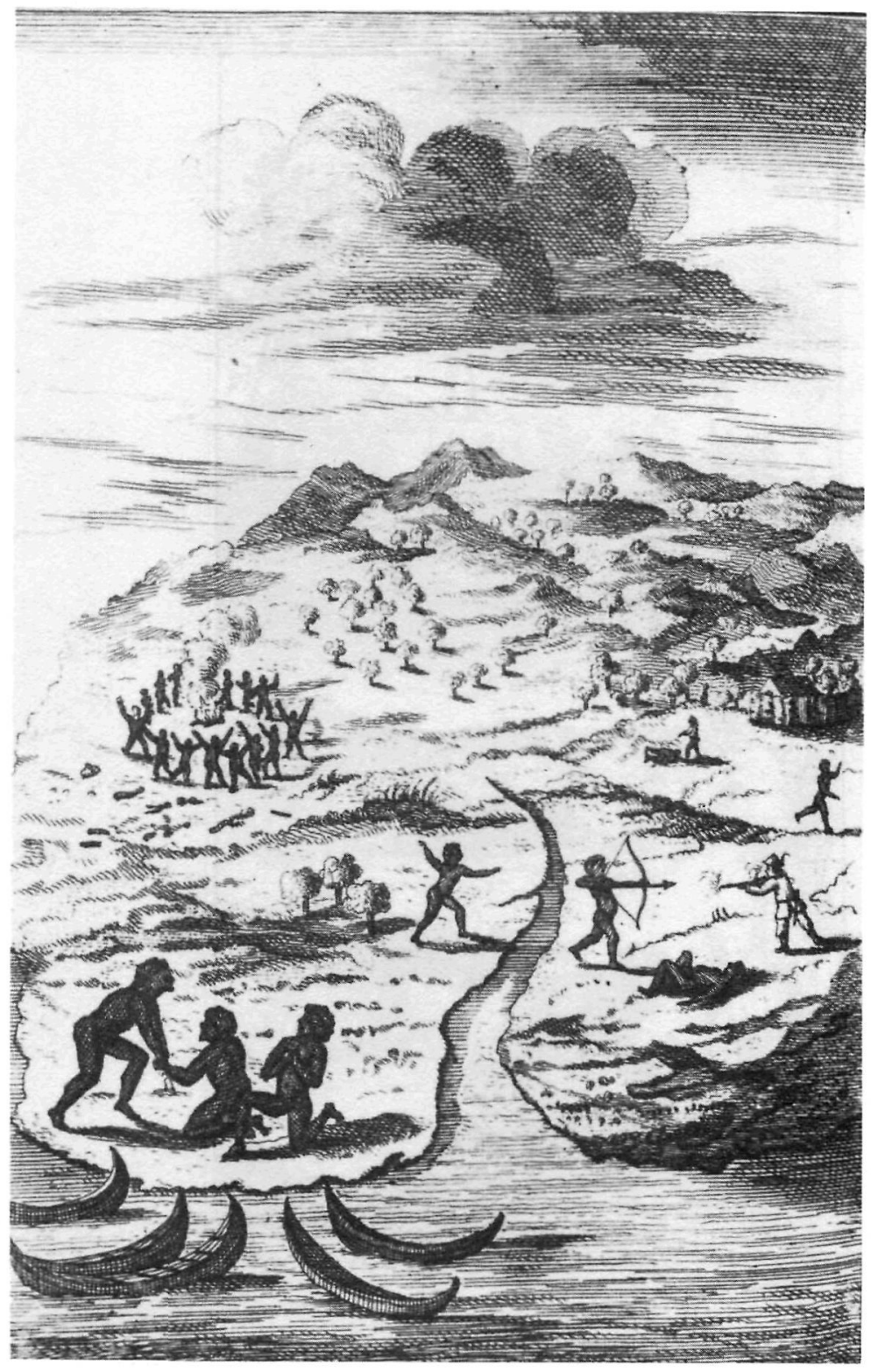

II Rescue scene Anon. 1722 


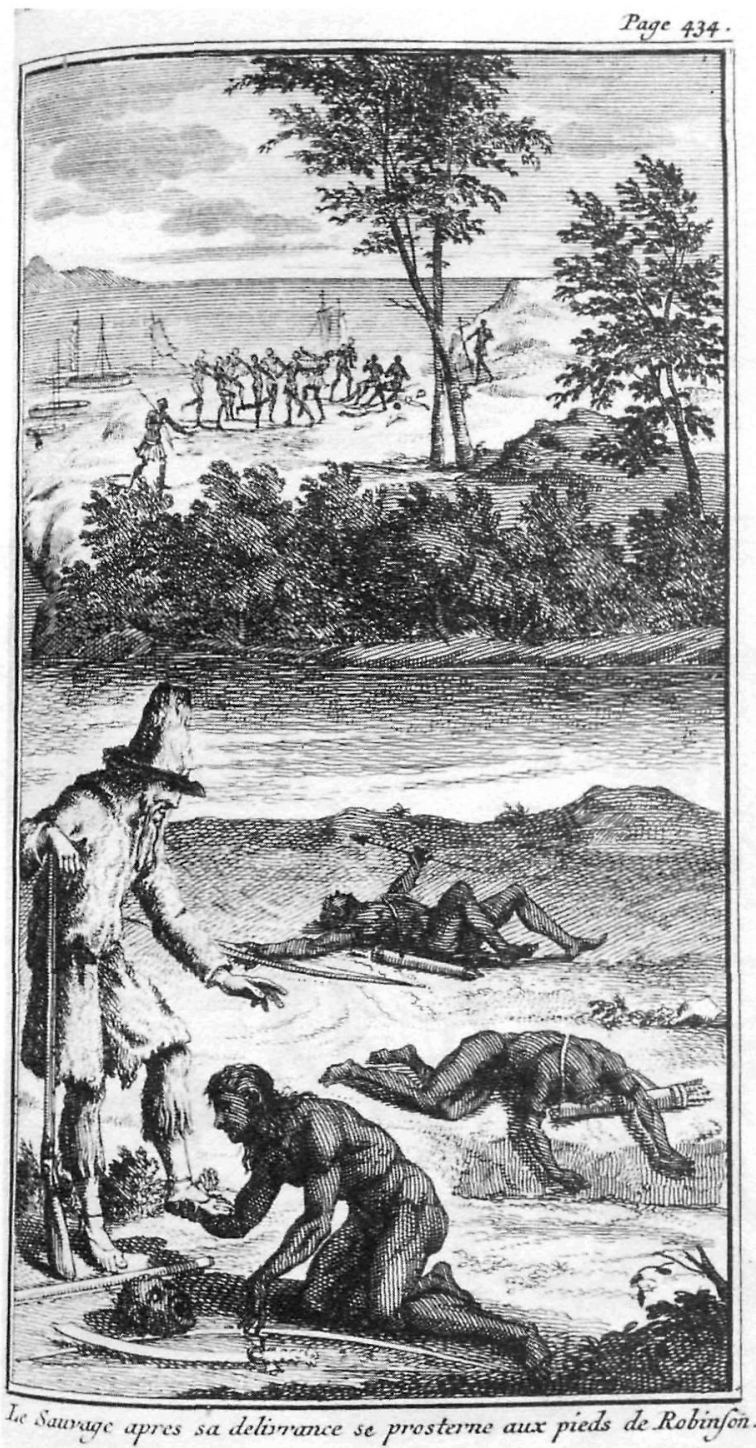

III Rescue scene Anon. (Picart?) 1720 


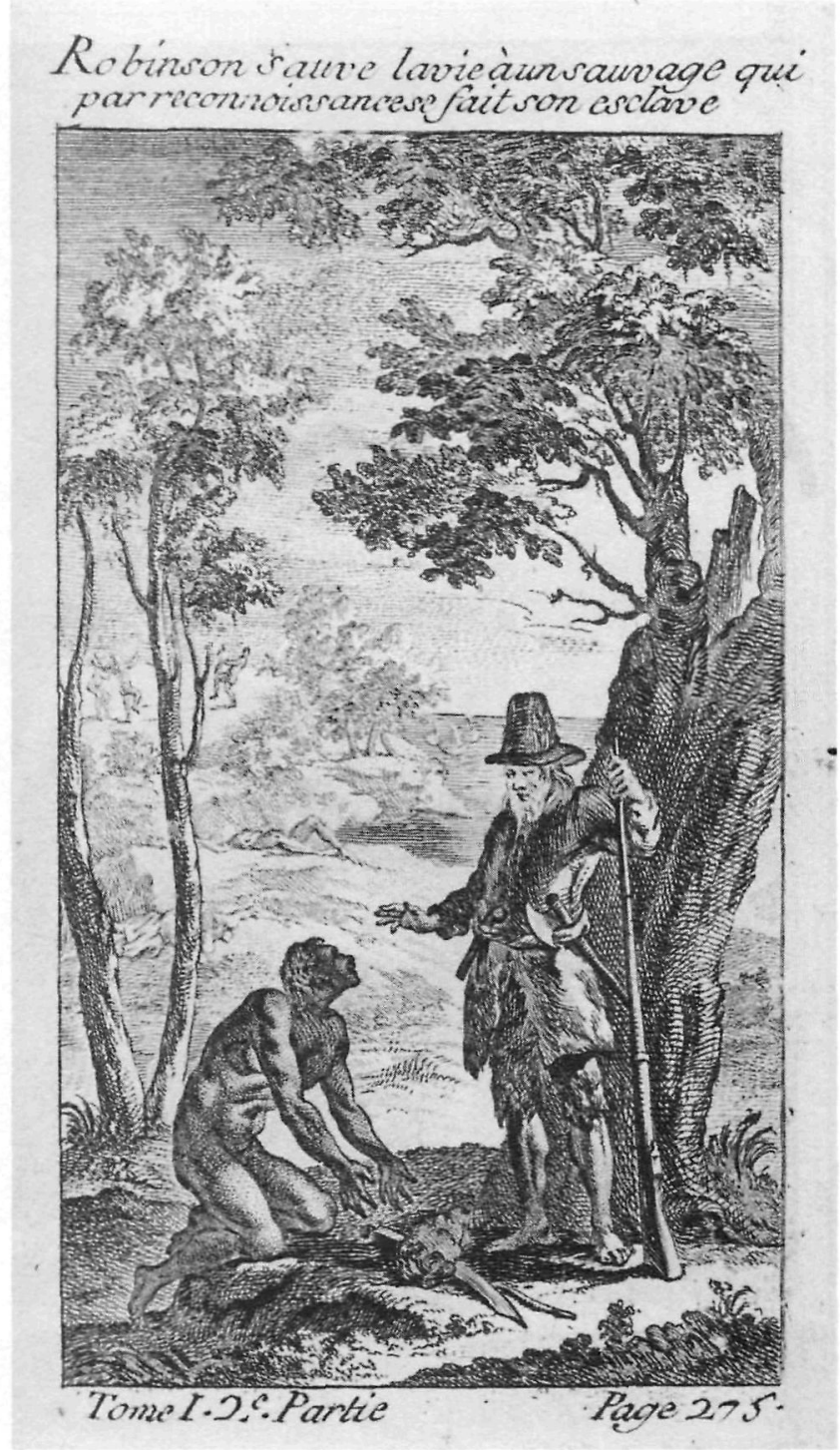

IV Rescue scene Anon. 1761 


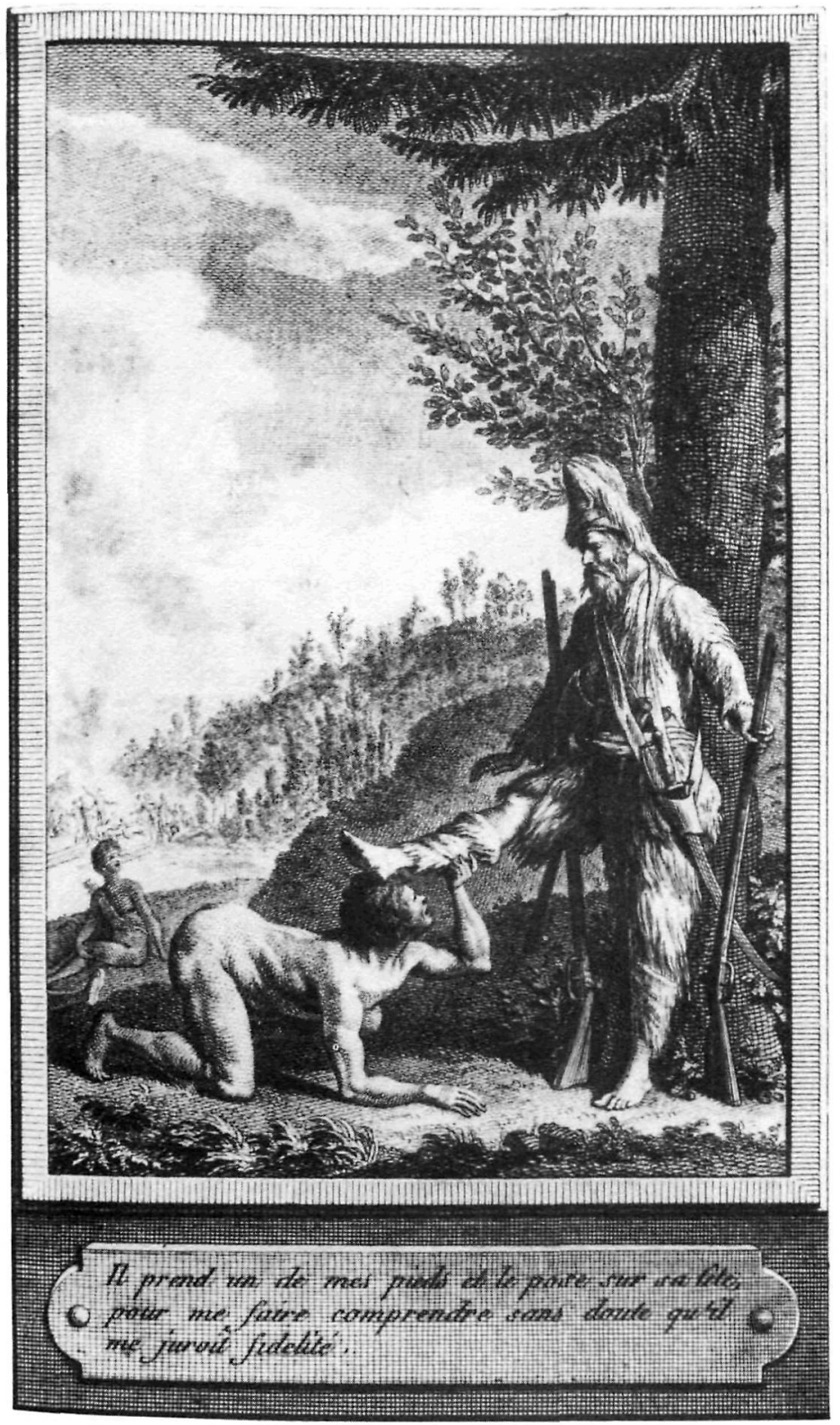

V Rescue scene C.P. Marillier - R.H.J. Delvaux 1787 


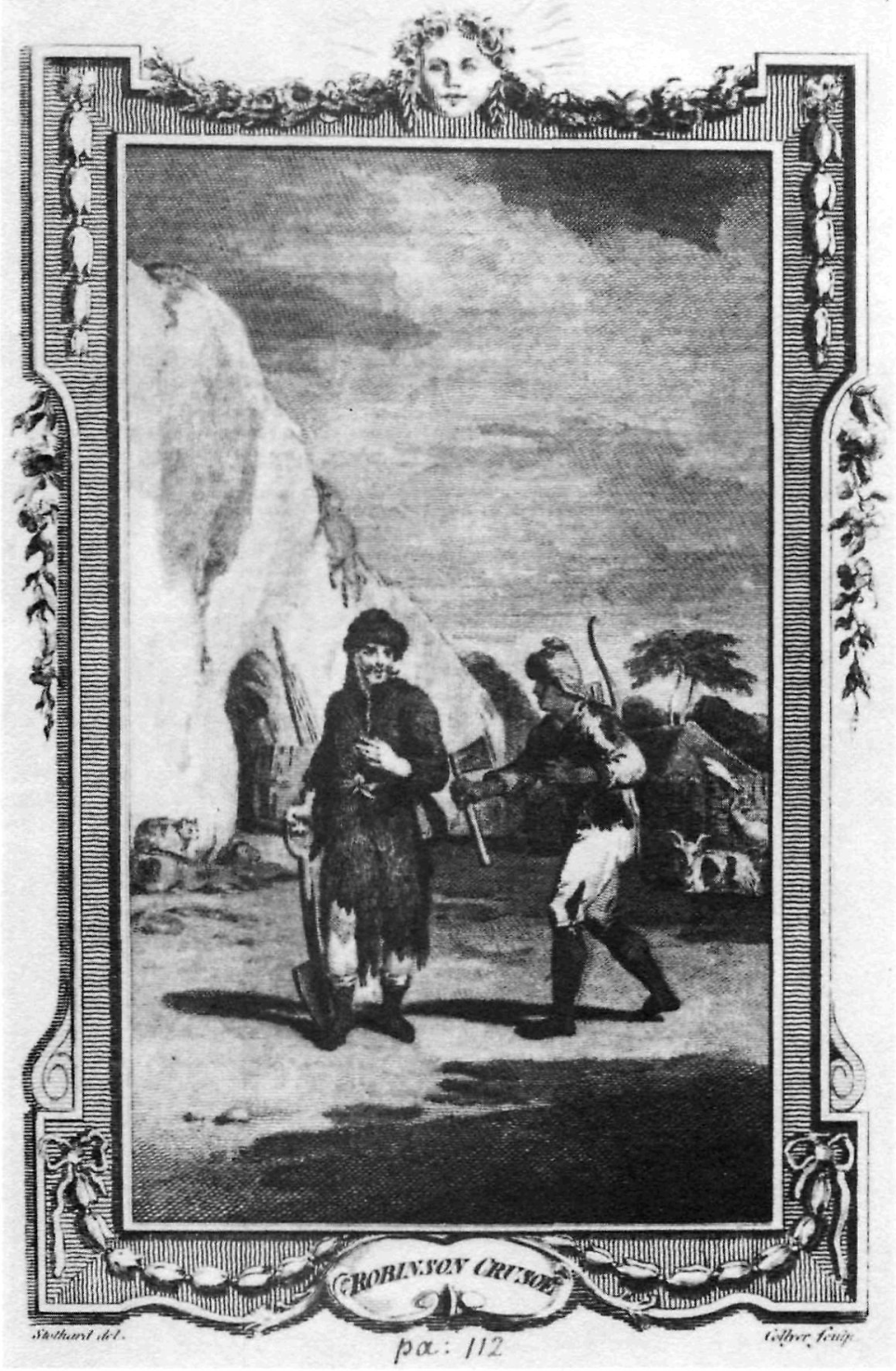

VI Crusoe and Friday T. Stothard -J. Collyer 1781 


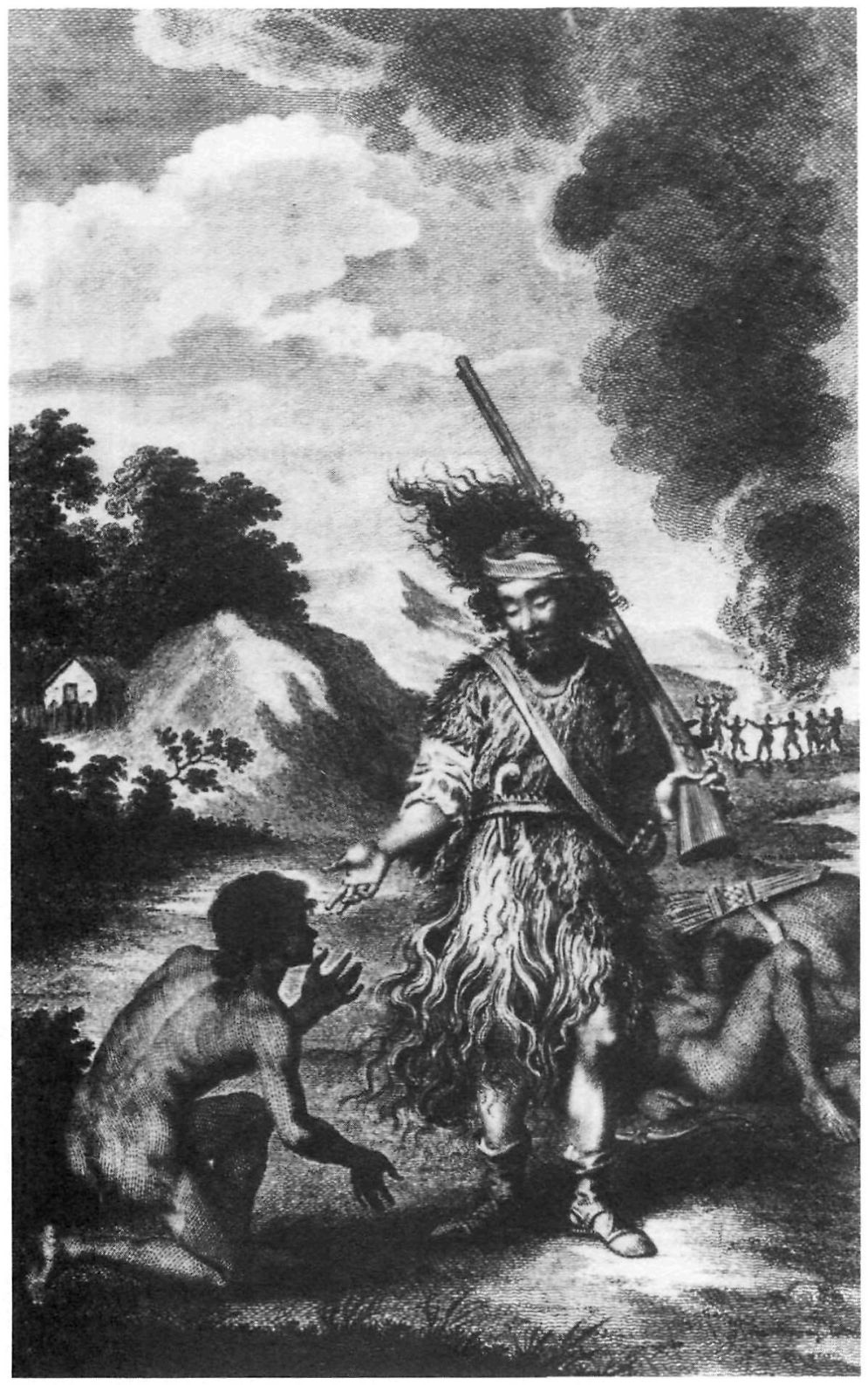

VII Rescue scene M. Brown - R. Pollard 1785 


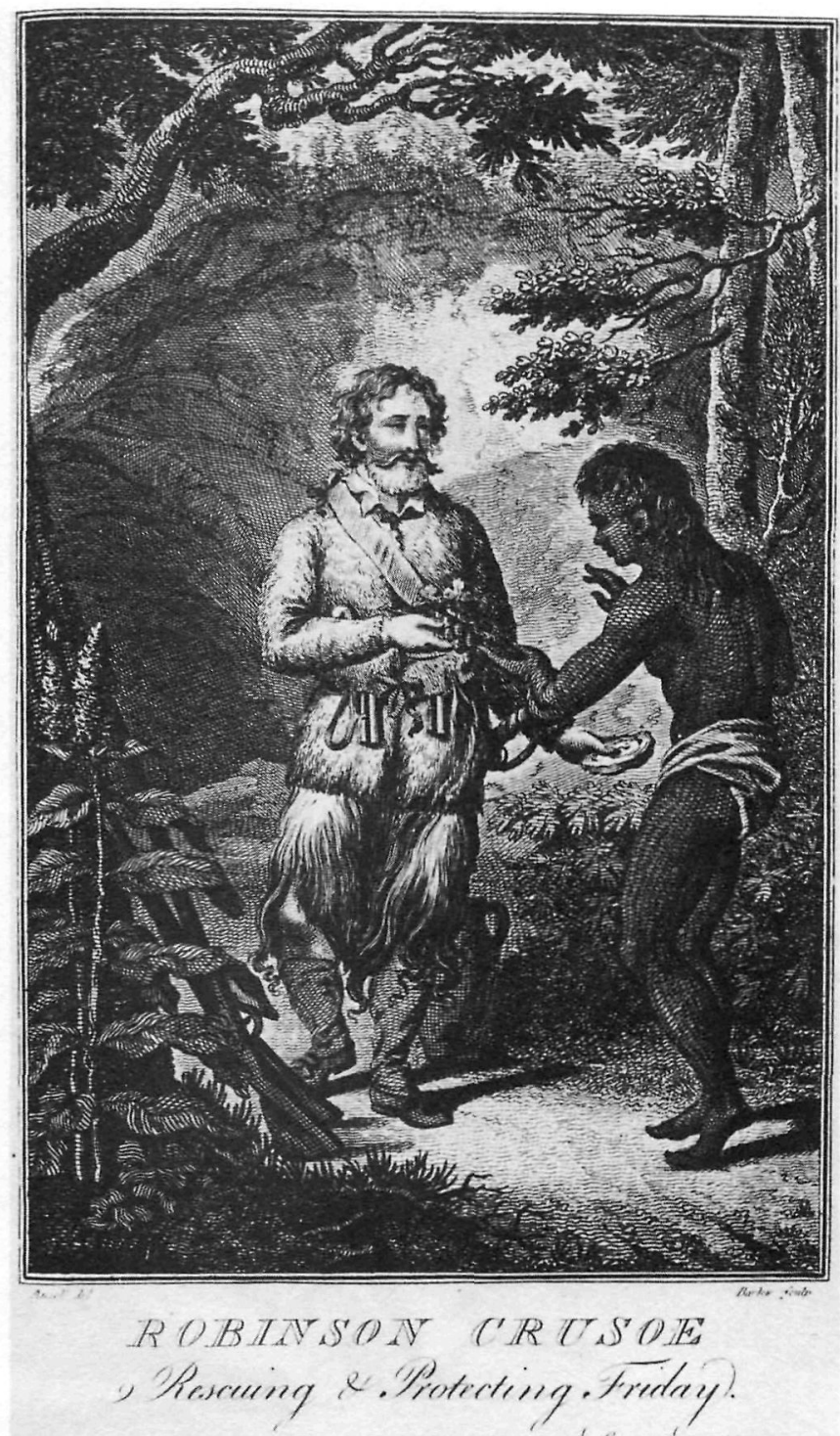

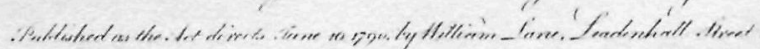

VIII Rescue scene C. Ansell - J. Barlow 1790 


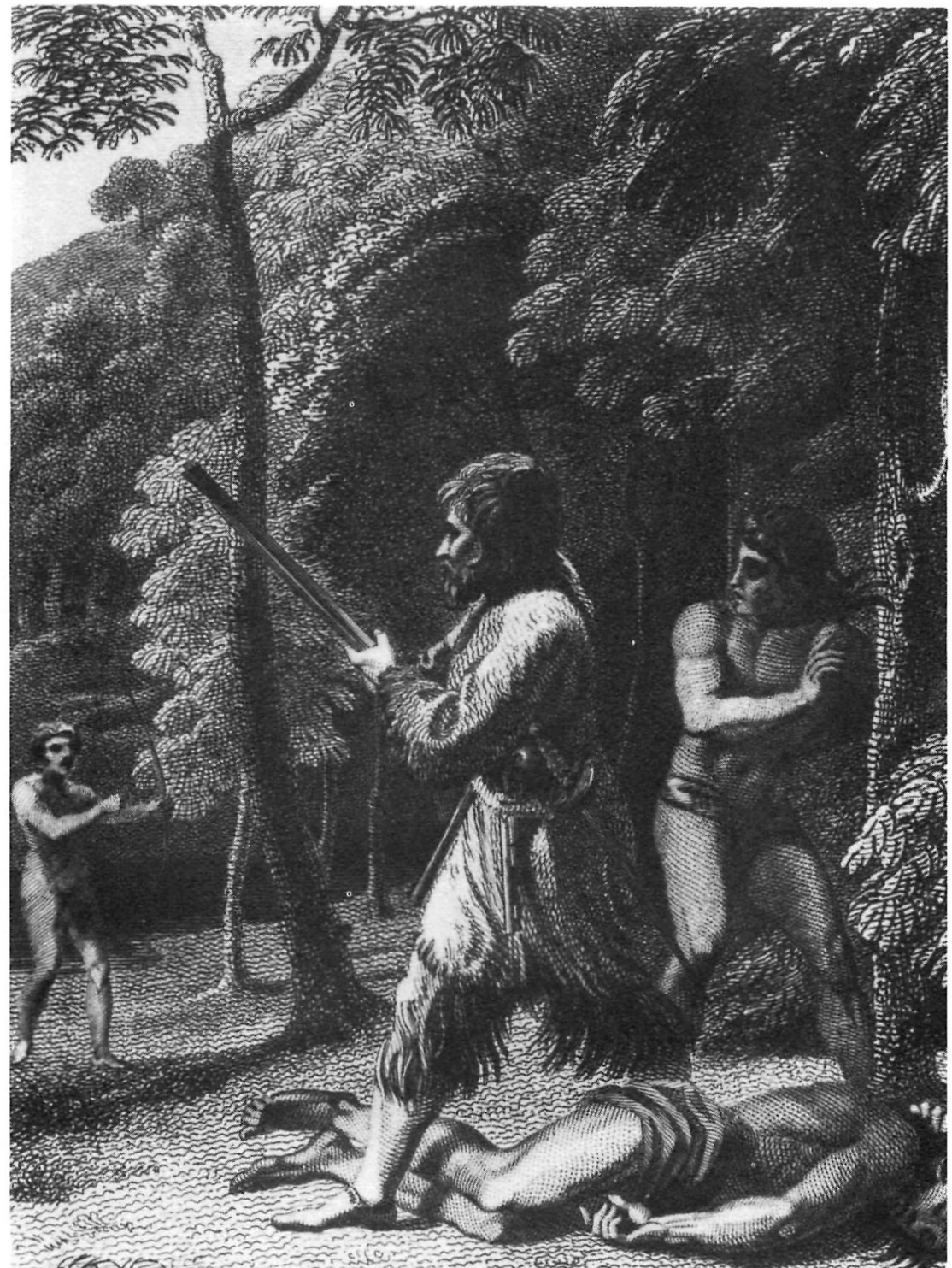

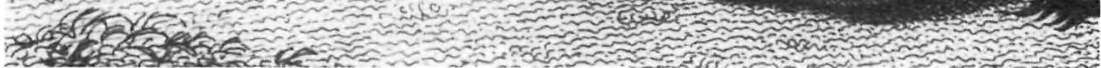

IX Rescue scene T. Stothard - T. Medland 1790 


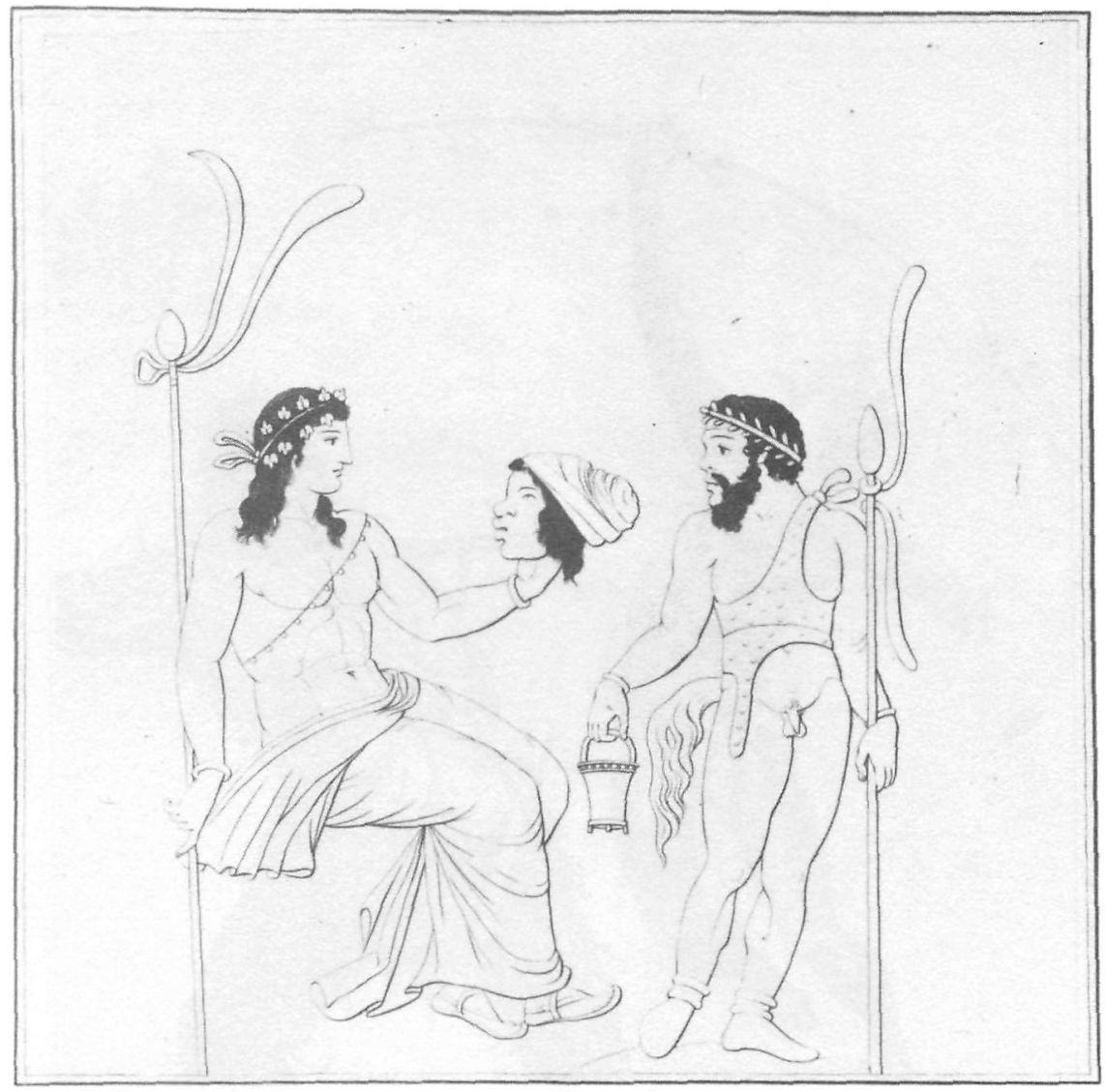

$X$ Noble profile [Hamilton Collection of antique vases] 


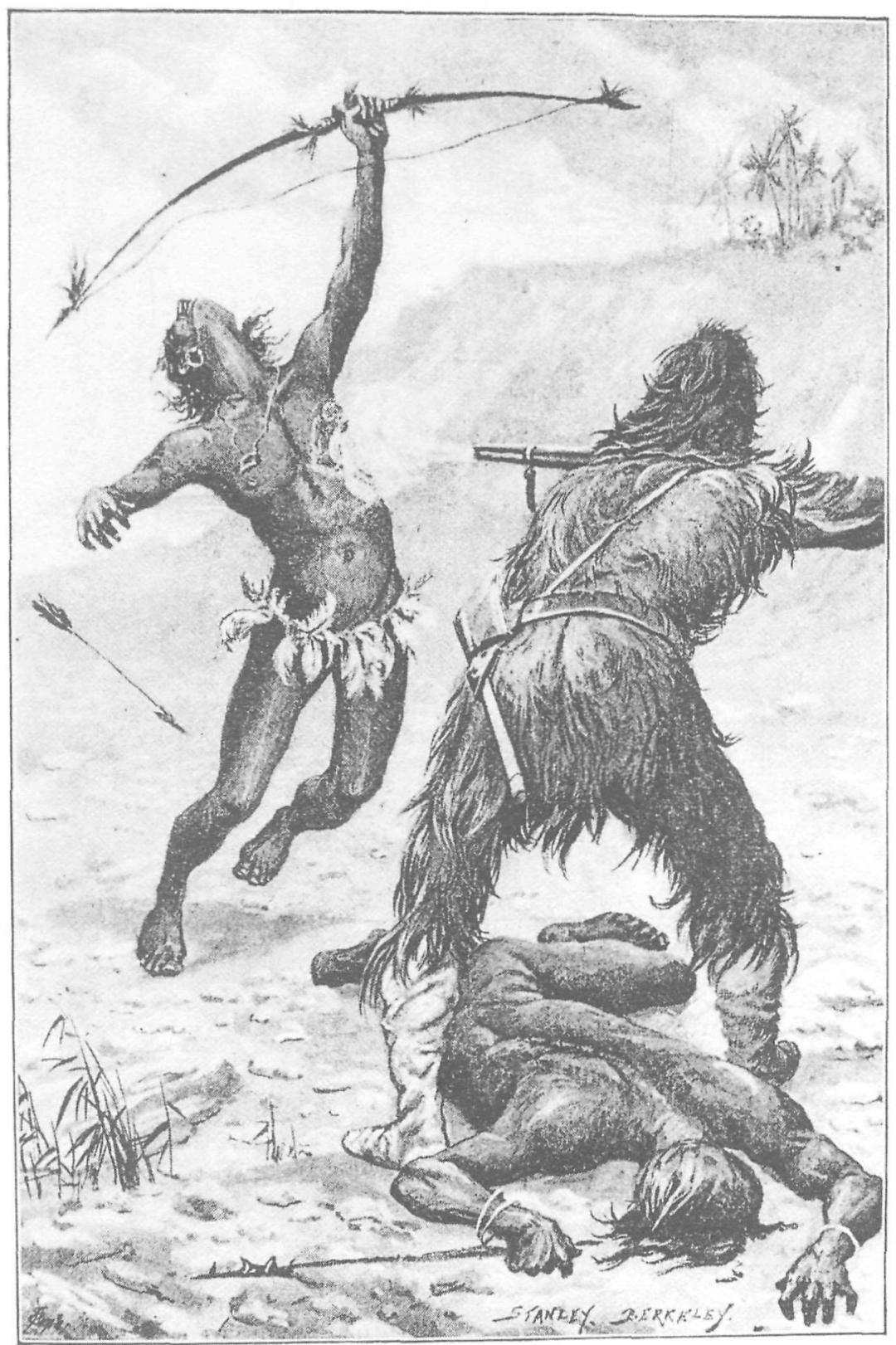

XI Rescue scene Stanley Berkeley 1890 


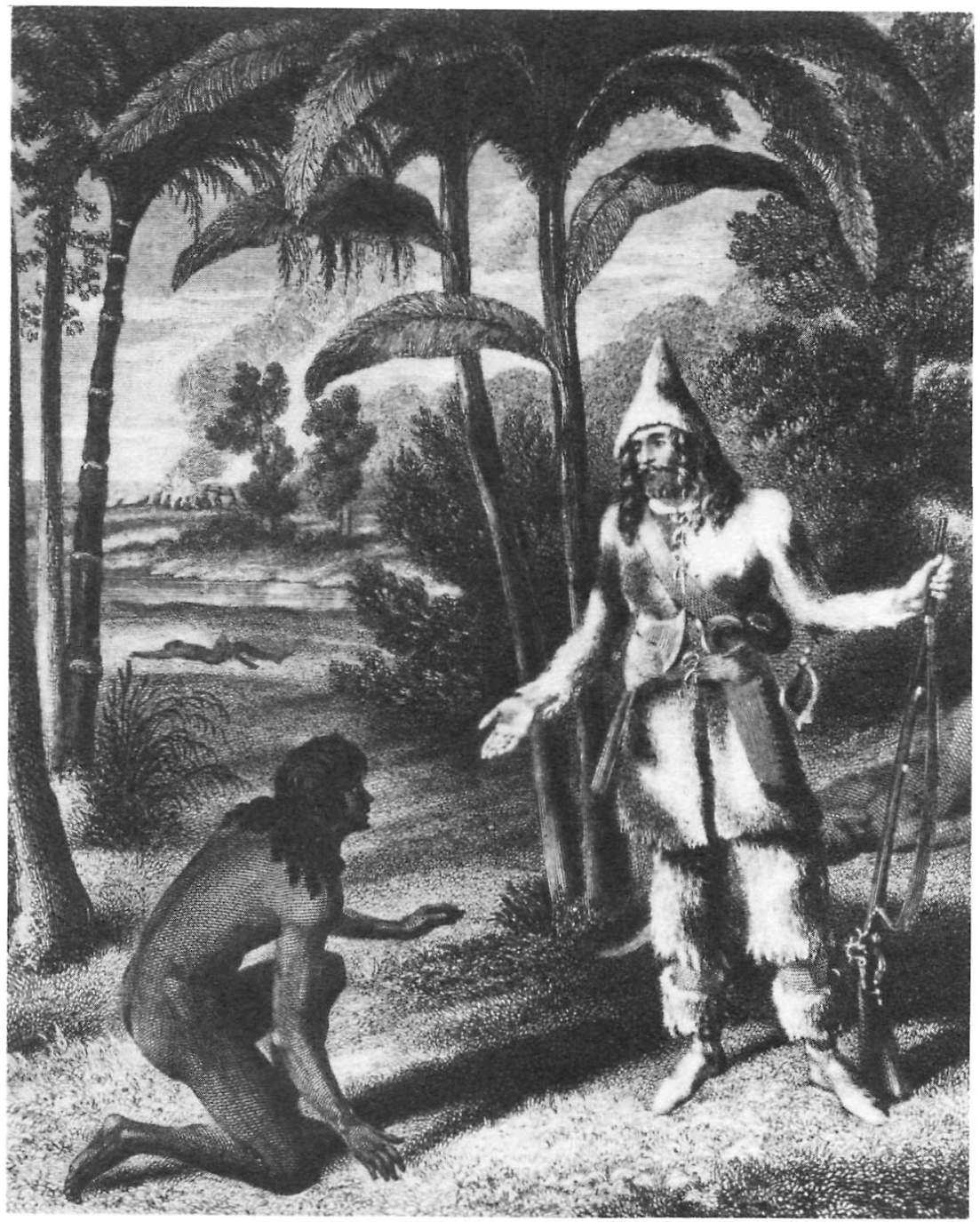

XII FP rescue scene G. Cruikshank - Augustus Fox 1831 